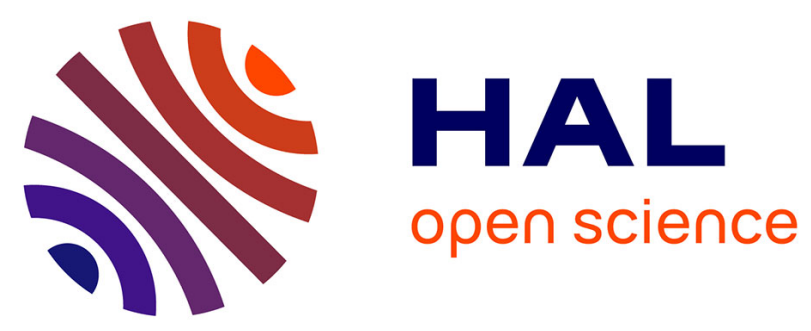

\title{
Feeding the world: genetically modified crops versus agricultural biodiversity
}

Sven-Erik Jacobsen, Marten Sørensen, Søren Pedersen, Jacob Weiner

\section{To cite this version:}

Sven-Erik Jacobsen, Marten Sørensen, Søren Pedersen, Jacob Weiner. Feeding the world: genetically modified crops versus agricultural biodiversity. Agronomy for Sustainable Development, 2013, 33 (4), pp.651-662. 10.1007/s13593-013-0138-9 . hal-01201389

\section{HAL Id: hal-01201389 \\ https://hal.science/hal-01201389}

Submitted on 17 Sep 2015

HAL is a multi-disciplinary open access archive for the deposit and dissemination of scientific research documents, whether they are published or not. The documents may come from teaching and research institutions in France or abroad, or from public or private research centers.
L'archive ouverte pluridisciplinaire HAL, est destinée au dépôt et à la diffusion de documents scientifiques de niveau recherche, publiés ou non, émanant des établissements d'enseignement et de recherche français ou étrangers, des laboratoires publics ou privés. 


\title{
Feeding the world: genetically modified crops versus agricultural biodiversity
}

\author{
Sven-Erik Jacobsen • Marten Sørensen • \\ Søren Marcus Pedersen • Jacob Weiner
}

Accepted: 18 February 2013 / Published online: 19 March 2013

(C) INRA and Springer-Verlag France 2013

\begin{abstract}
The growing demand for food poses major challenges to humankind. We have to safeguard both biodiversity and arable land for future agricultural food production, and we need to protect genetic diversity to safeguard ecosystem resilience. We must produce more food with less input, while deploying every effort to minimize risk. Agricultural sustainability is no longer optional but mandatory. There is still an on-going debate among researchers and in the media on the best strategy to keep pace with global population growth and increasing food demand. One strategy favors the use of genetically modified (GM) crops, while another strategy focuses on agricultural biodiversity. Here, we discuss two obstacles to sustainable agriculture solutions. The first obstacle is the claim that genetically modified crops are necessary if we are to secure food production within the next decades. This claim has no scientific support, but is rather a reflection of corporate interests. The second obstacle is the resultant shortage of research funds for agrobiodiversity solutions in comparison with funding for research in genetic modification of crops. Favoring biodiversity does not exclude any future biotechnological contributions, but favoring biotechnology threatens future biodiversity resources. An objective review of current knowledge places GM crops far down the list of potential solutions in the coming decades. We conclude that much of the research funding currently available for the development of GM crops would
\end{abstract}

S.-E. Jacobsen $(\square) \cdot$ M. Sørensen $\cdot$ J. Weiner Department of Plant and Environmental Sciences,

University of Copenhagen, Thorvaldsensvej 40,

1871 Frederiksberg, Denmark

e-mail: seja@life.ku.dk

\section{S. M. Pedersen}

Institute of Food and Resource Economics,

University of Copenhagen, Rolighedsvej 25,

1958 Frederiksberg, Denmark be much better spent in other research areas of plant science, e.g., nutrition, policy research, governance, and solutions close to local market conditions if the goal is to provide sufficient food for the world's growing population in a sustainable way.

Keywords GMO · Underutilized crops · Andean crops · Food production $\cdot$ Agrobiodiversity $\cdot$ Sustainability

\section{Introduction}

It is predicted that the human population will reach nine billion within coming decades, and this is of urgent concern as already ten children die of starvation per minute (Pinstrup-Andersen 2010a, b). To keep pace with population growth, it is estimated that in the next 40 years food production must increase greatly with the limited availability of arable land, water, and fossil fuels, exacerbated by climate change (ISF 2011). One billion people in the world face starvation and two billion people suffer one or more micronutrient deficiencies, especially vitamin A, iodine and iron, often lumped as hidden hunger (Alnwick 1996).

Agriculture is the primary source of food, but modern, intensive agriculture is in general a burden on the environment, resulting in contamination of drinking water, soil degradation, erosion, and reducing biodiversity (Frison et al. 2011). Large modern farms specialize in livestock and a few species of crops, grown as monocultures of genetically uniform individuals. Larger fields reduce the extent of field margins and hedgerows with their reserves of biodiversity, while loss of soil organic matter degrades the productivity of soils. The expected increase in monoculture production for biofuels such as sugarcane, maize, and soybean, and oil crops such as oil palm, will further increase loss of genetic material, as will the rapidly increasing demand for nonfood 
products like coffee by the growing middle classes of Brazil, Russia, India, and China.

To increase food production in order to meet the demand from an expanding world population while being faced with anticipated climate changes will definitely entail increased access to genetic resources (Juma 2011). For example, the expected changes in the growing season of various crops will require intensified crop breeding efforts (Burke et al. 2009). The prerequisites of such breeding programs encompass not only knowledge of existing practices but also conservation of a wide pool of genetic resources of existing crops and breeds, including their wild relatives, to provide the genes necessary to cope with changes in agricultural production. Therefore, agrobiodiversity ${ }^{1}$ should be a central element of sustainable agricultural development, instead of simply a source of traits that can be used in current breeding programs (Conner and Mercer 2007; Huang et al. 2002; Salinger 2012; Welch and Graham 2004). The concept of sustainability rests on the principle that the needs of the present must be addressed without compromising the ability of future generations to meet their own needs (Lichtfouse et al. 2009). Sustainable agriculture is an alternative for solving fundamental and applied issues related to food production in an ecological way (Lal 2008).

The present debate about how to increase global food production has focussed on arguments for or against genetically modified organisms or genetically modified (GM) crops $^{2}$. One important issue is the effect of the widespread use of GM crops on biodiversity. The sequencing of genomes provides capacity for selective breeding of crops suited to diverse ecologies. Technological advancement is therefore helping to augment nature's diversity and expand adaptive capabilities (Juma 2011).

Farmers in developing countries, especially small-scale farmers, have problems that are specific to their cultural, economic and environmental conditions, such as limited purchasing power to access proprietary technologies. Hence, the spillover from private sector research in developed countries has therefore had limited impact on the livelihoods of subsistence farmers in developing countries (FAO 2010). GM crops and their creation may attract investment in agriculture, but it can also concentrate ownership of agricultural resources. In developing countries, patents may drive up costs, restrict experimentation by the individual farmer or public researcher, while undermining local practices that enhance food security and economic sustainability. There is particular concern that present intellectual property rights instruments, including genetically

\footnotetext{
${ }^{1}$ Agrobiodiversity defined as: all non-GM cultivated species including varieties and landraces.

${ }^{2} \mathrm{GM}$ crops are defined here as new varieties of crop species developed by molecular modification through the insertion of foreign genetic material.
}

modified organisms (GMOs), will inhibit sowing of own seeds, seed exchange, and sale (IAASTD 2009).

The introduction of GMO technology has been hailed as a gene revolution similar to the green revolution of the 1950s (Pingali and Raney 2005; Jain 2010). The green revolution had an explicit strategy for technology development and diffusion, targeting farmers in developing countries, in which improved germplasm was made freely available as a public good, and was in particular a success in Asia. Rice yields in India rose from 2 t/ha in 1960 to $6 \mathrm{t} /$ ha in 1990 , with a simultaneous reduction in price from $550 \mathrm{USD} / \mathrm{t}$ in 1970 to 200 in 2001 (Barta 2007). In contrast to the green revolution, the push for GMOs is based largely on private agricultural research, with varieties provided to farmers on market terms (Pingali and Raney 2005).

Our objective of this review paper is to analyze the benefits and disadvantages of the development of plant breeding based on the use of existing agrobiodiversity compared to the use of GMO technology, for securing and increasing global food production.

\section{Genetically modified crops}

\subsection{Status of GM crops}

Numerous recent articles and declarations extol the potential of GM crops for world food production (Schiøler and Pinstrup-Andersen 2009; Pinstrup-Andersen 2010b; Carpenter 2010). As Schiøler and Pinstrup-Andersen (2009) ask, ought we not to use the best research we can offer to increase food production, and do we not need new technology to meet the increased demand for food? Another question, would the discarding of genetic modification technology as a viable option not be against the best interest of human wellbeing (Beyer 2010)? Some proponents have gone so far as to argue that GM crops are the only solution to the globe's future need for plant-based food production (Borlaug 2000; Trewavas 2002). The question is whether genetically modified plants represent the best option available. One could easily get the impression that most modern crop research has a molecular focus and is related to the development of GM crops, while other areas such as plant biodiversity, crop physiology and cropping systems research attract less attention, in spite of their obvious relevance for the problems facing the world's food supply.

GM crops are being taken up faster than any other agricultural technology since the plow 8,000 years ago, and are presently being used by 16 million farmers (James 2011). On a global scale, farmers have rapidly adapted to GM crops (Lawson et al. 2009). The first commercial GM crop was sown in China in 1992. The countries with the largest area of GM crops today are the USA followed by Argentina, 
Brazil, Canada, and India (GM Compass 2009), with a total area in 2009 of 134 million ha, which in 2011 has increased to 160 million ha (James 2011). Soybean accounts for more than half of the GM crops and is used mostly for high protein animal feed (Vidal 2011a). The major GM crops apart from soybean are cotton, maize and oilseed rape, and the most common genetically introduced traits are herbicide (glyphosate) tolerance, and Bt toxins that makes the crop plants inedible to some insects. The world's three largest companies, utilizing plant gene technology, Monsanto, Dupont and Syngenta, now control nearly $70 \%$ of global seed sales (Vandana et al. 2011).

In USA, the speed with which GM crops have spread has been impressive, since large-scale adoption began in 1996 (Enriquez 2001). According to a recent update on US agriculture, the proportion of GM to non-GM crops were $73 \%$ for maize, $87 \%$ for cotton, and $91 \%$ for soybean (USDA 2007). At one point, the limiting factor for the sowing of soybean resistant to glyphosate (Roundup ${ }^{\circledR}$ ) was the availability of seeds (Carpenter and Gianessi 1999). While North American farmers have been very keen to accept this new technology, adoption has been very slow in Europe due to strong public opposition. The opposition has been so severe, that in the EU only 114,500 ha of arable land is grown with Bt maize as the only GM crop, mostly in Spain (James 2011 ), i.e., $\sim 0.01 \%$ of the European agricultural area.

\subsection{Pros and cons of GMOs}

Unlike other biotechnologies, e.g., tissue culture, markerassisted breeding, and medicine production by GM bacteria, GM crops have often been the subject of heated controversy (Stone 2010). What are the reasons?

Monsanto has control over $95 \%$ of the Indian cotton seed market and this near monopoly has resulted in greatly increased prices (Vidal 2011b). It has claimed to have led to high levels of indebtedness among farmers. In India, about 250,000 farmers died by suicide over the past 15 years (Guillaume et al. 2008; ISIS 2010). This cannot be attributed directly to the GM crops as such, but may for a large part be due to inappropriate marketing. Farmers have been promised higher yields and lower pesticide costs when using GM crops, primarily those with the Bt gene, thus they acquired loans to afford the costly seeds. When, in many cases, the farmers found that the yields failed to meet the expected result, the consequences have been serious (Vidal 2011b). This can also be illustrated by the adoption of Bt cotton in the Indian states of Andhra Pradesh and Maharashtra. The absence of irrigation systems combined with specialization in high-cost crops and low prices played a role in indebtedness of some farmers in the suicide-prone areas. However, none of these possible links to the high suicide frequency has been thoroughly examined with a sufficiently robust analysis (Gruère et al. 2008). Even then, Ahmed (2012) opines that Monsanto's operation in India illustrates monopolization and manipulation of the market economy, especially when corruption is rampant.

The plants from Bt cotton seed have been effective in controlling damage from bollworm (Helicoverpa armígera) in Chinese cotton production since 1999, reducing the need for pesticides and increasing incomes of Chinese farmers. However, field data collected in 2004 indicates that these benefits are being eroded by an increasing use of pesticides aimed at the control of secondary pests (Wang et al. 2008). This is confirmed by Wang et al. (2009), who claimed that the increased problems with secondary pests were of less importance than the decreased use of insecticide due to growing of Bt cotton. In US maize, another pest, the rootworm, has developed resistance to the toxin from $\mathrm{Bt}$, as reported by the Environmental Protection Agency (Gassmann et al. 2011). GM crops may potentially offer some solutions to future food production, but one can argue that the main thrust of GM crop research to date instead has been to increase farmers' dependence on the agro-industry (Tirado and Johnston 2010).

One of the major arguments for GM technology is that new varieties can be developed more quickly than in traditional plant breeding (Parry and Hawkesford 2012), but like new cultivars derived from conventional breeding methods, GM cultivars require several years of field trials to ensure that the inserted traits will actually become expressed and have the desired effects in local environments. When genes coding for certain traits are transferred, typically from one plant species to another, the desired traits are not always expressed unless the environment interacts with the genes in the anticipated way that triggers the desired response, which depends on the regulating sequences inserted with the gene. This means that new GM cultivars, developed under laboratory conditions in a controlled climate, have to be tested under field conditions, as in more traditional breeding methods, so currently there is little difference in the speed with which either method will result in the release of new cultivars. A special time consuming phase of the GMO method is associated with the identification, isolation, and characterization of the desired gene and the initial tests in the model plant. Not before this has been accomplished may the gene be inserted in numerous species of known adaptation to specific environments (Gepts 2002; Ulukan 2009).

An argument occasionally presented in favor of the use of GM crops is the so-called beneficial trade-off between lowyielding extensive agricultural systems involving traditional crops, which require more land to produce the same amount of food, and high-yielding intensive systems, which require less land for agricultural use and therefore spare land and minimize the negative impact on biodiversity on noncultivated land. However, there are several arguments in favor of the extensive 
system, including increased sustainability and less impact from stresses caused by drought, insects, and diseases, due to longterm in situ selection of the crops cultivated less as opposed to the fertilizer, herbicide, and pesticide demands in an intensive GM crop-based system (IFOAM 2009; Carpenter 2010).

A successful adoption of GM crops depends on several aspects such as public perception of risks and benefits of GM technology; a country's participation in international environmental agreements and agroindustry to support the adoption (Hall et al. 2009).

\subsection{Economics}

Experience from the USA shows that GM crops can sometimes offer net environmental and economic benefits compared to conventional crops, but often this is not the case. Some benefits are expected to decline over time, and potential benefits and risks may become more numerous as the technology is applied to more crops (NAS 2010).

Adoption of herbicide-tolerant GM crops is mainly a laborsaving technology which may benefit farms in high income, developed countries, by simplifying weed control procedures and thereby reduce a labor-intensive weeding practice. In many developing countries, labor abounds at low cost, implying that the relative benefit from reduced weeding is much less significant, while the GM seeds are more expensive than seeds of non-GM varieties - not to mention the stabilizing sociopolitical implications from the jobs offered when labor demanding methods are employed. A review on the economic impact of insect-resistant $(\mathrm{Bt})$ maize indicates that farmers may gain improved gross margins up to $70 \mathrm{USD} / \mathrm{ha}$. In the USA, which contains about $50 \%$ of the GMO area in the world, the increase in gross margins from Bt maize was only $12 \mathrm{USD} / \mathrm{ha}$, whereas for Bt cotton there seems to be significant gains in relation to increased yields and reduction of insecticides in countries like China, India, and Mexico (Qaim 2009).

Gruère and Sun (2012) showed that Bt cotton contributed significantly to cotton yield growth, with $0.29-0.39 \%$ annual yield increase per percent adoption, or a total $19 \%$ increase from 1975 to 2010 . However, the results show that other key factors than the $\mathrm{Bt}$ trait had a significant effect, especially the use of fertilizers and of hybrid seeds. Human labor, pesticides, and the use of irrigation were also found to be important.

Of 168 datasets comparing yields of GM and conventional crops, 124 showed increased yields for adopters, 32 indicated no difference, and 13 are negative (Carpenter 2010). According to The Union of Concerned Scientists, a science-based nonprofit organization, the record of GM crops in contributing to increased yield is modest in the USA, despite considerable efforts (Gurian-Sherman 2009). Higher production is often associated with reduced profit for the farmer due to increased costs.
The economic gains by farmers in different regions will also depend on market policies, seed costs, access to labor, and water in different regions as well as farm structure. For instance, smallholder farmers that adopted Bt varieties of white maize in South Africa did benefit from planting Bt maize in high maize stalk borer infestation years, but when planted in locations or years when stalk borers were not a problem, Bt was not profitable because of higher seed costs (Gouse et al. 2006).

The use of patents for transgenic crops introduces additional problems according to the IAASTD (2009) report developed with the contribution from 400 scientists around the world, and adopted by 58 governments. In developing countries, especially, instruments such as patents drive up costs and restrict experimentation by individual farmers while also potentially undermining local practices for securing food and economic sustainability. Thus, there is particular concern regarding present intellectual property rights instruments, which may inhibit seed-saving, exchange, sale, and access to proprietary materials of vital importance to the independent research community, specifically in view of the need for analyses and long term experimentation on climate change impacts.

Arguments for the adoption of Bt-GM crops have focused on the benefits in reduced use of insecticide saving and to sometimes increased yield, but the farmer will usually have to pay more for the seeds. A study from Spain on Bt maize indicate an increase in gross margins of EUR 68-266/ha compared with conventional crops (Brookes 2002). However, the investments and benefits did not include any costs in relation to regulation and control measures to ensure traceability in the supply chain. Depending on the national regulations, and to secure traceability and consumers' free choice, farmers may have to add costs for control and cleaning measures both at the farm level as well as in the supply chain. These costs may vary depending on the crop and location. For instance, the Danish legislation on GM crops requires that farmers have to clean the equipment and pay an insurance fee for growing GM crops. For certain crops, e.g., oilseed rape, a buffer zone between the GM crop and neighbor crops is required. For sugar beet and potatoes, it should be possible to gain an extra net benefit from GM crops, but for maize the benefit is negative due to small savings in relation to the cost of coexistence with non-GM crops (Table 1).

Coexistence cost is the cost that may occur to ensure that both GM crops and conventional crops can be cultivated next to each other and to ensure traceability in the supply chain without contamination of the end non-GM product, and to ensure that the end-consumer has a free choice (Table 1). Costs to include are for cleaning machinery, insurance costs in case of contamination, and costs related to separate GM and non-GM crops in the field and in the supply chain. One unit of pesticide treatment index is 
Table 1 Estimated net benefits for GM crops at farm level (Danish Ministry of Food Agriculture and Fisheries 2009)

\begin{tabular}{|c|c|c|c|c|c|}
\hline & \multicolumn{2}{|l|}{ Sugar beet } & \multicolumn{2}{|l|}{ Maize } & \multirow{2}{*}{$\begin{array}{l}\text { Potatoes } \\
\text { Current } \\
\text { pesticide use }\end{array}$} \\
\hline & $\begin{array}{l}\text { Current } \\
\text { pesticide use }^{\mathrm{a}}\end{array}$ & $\begin{array}{l}\text { Good conventional } \\
\text { practice }^{b}\end{array}$ & $\begin{array}{l}\text { Current } \\
\text { pesticide use }^{\mathrm{a}}\end{array}$ & $\begin{array}{l}\text { Good conventional } \\
\text { practice }^{\mathrm{b}}\end{array}$ & \\
\hline Savings in crop protection (EUR/ha) & 156.00 & 128.00 & 36.00 & 15.00 & 219.00 \\
\hline Coexistence costs (seed cost, cleaning) (EUR/ha) & 76.00 & 76.00 & 41.00 & 41.00 & 110.00 \\
\hline Difference (EUR/ha) & 80.00 & 53.00 & -5.00 & -25.00 & 108.00 \\
\hline Pesticide treatment index $(\mathrm{PTI})$ reduction & 2.18 & 1.77 & 0.45 & 0.23 & 1.70 \\
\hline
\end{tabular}

Exchange rate: $1 \mathrm{EUR}=7,45 \mathrm{DKK}$

${ }^{a}$ Current pesticide use is based on statistical (bekæmpelsesmiddelstatistikken from 2007 from Danish Environmental Agency)

${ }^{\mathrm{b}}$ Good conventional practice is based on conventional practise among the Danish advisory service, which is equivalent to a common treatment strategy recommended by Danish crop advisors

equivalent to one treatment in the field for a specific crop with pesticides in a cropping season.

\subsection{Research funding}

A major part of the total public research funds for agriculture in Europe and elsewhere is allotted to projects using technically advanced methods associated with scientific prestige and corporate investments, but sometimes with dubious goals and questionable impacts (Scientific American 2009). One result could be that the biodiversity needed to achieve the best crop adaptation to local conditions is reduced and even threatened with extinction. As an example, in Denmark, GMO research has been funded with EUR 20 million in recent years from the Danish Research Council, whereas conventional crop research has only received EUR 4 million (Fig. 1). The European Commission has supported projects on GMOs in the order of EUR 300 million since the beginning of the Bio-Molecular Engineering Programme (European Union 2010).

While GM crops have received much attention and investment, traditional breeding has been focusing mostly on increasing yield (Gurian-Sherman 2009). Newer and sophisticated breeding methods using increasing genomic knowledge, but not GMO techniques, show promise for increasing yield. The large investment in the private sector indicates that research on genetically modified versions of major crops is expected to continue, while organic and other agroecological methods are not likely to attract a similar investment. This increased specialization and intensification of production systems have led to reduction in crop and livestock biodiversity, and increased genetic vulnerability and erosion (FAO 2007; Gepts 2006). It is thus hardly surprising that the 2010 biodiversity targets were not met (Larigauderie and Mooney 2010). Nearly 17,000 species of plants and animals are currently at risk of extinction, and the
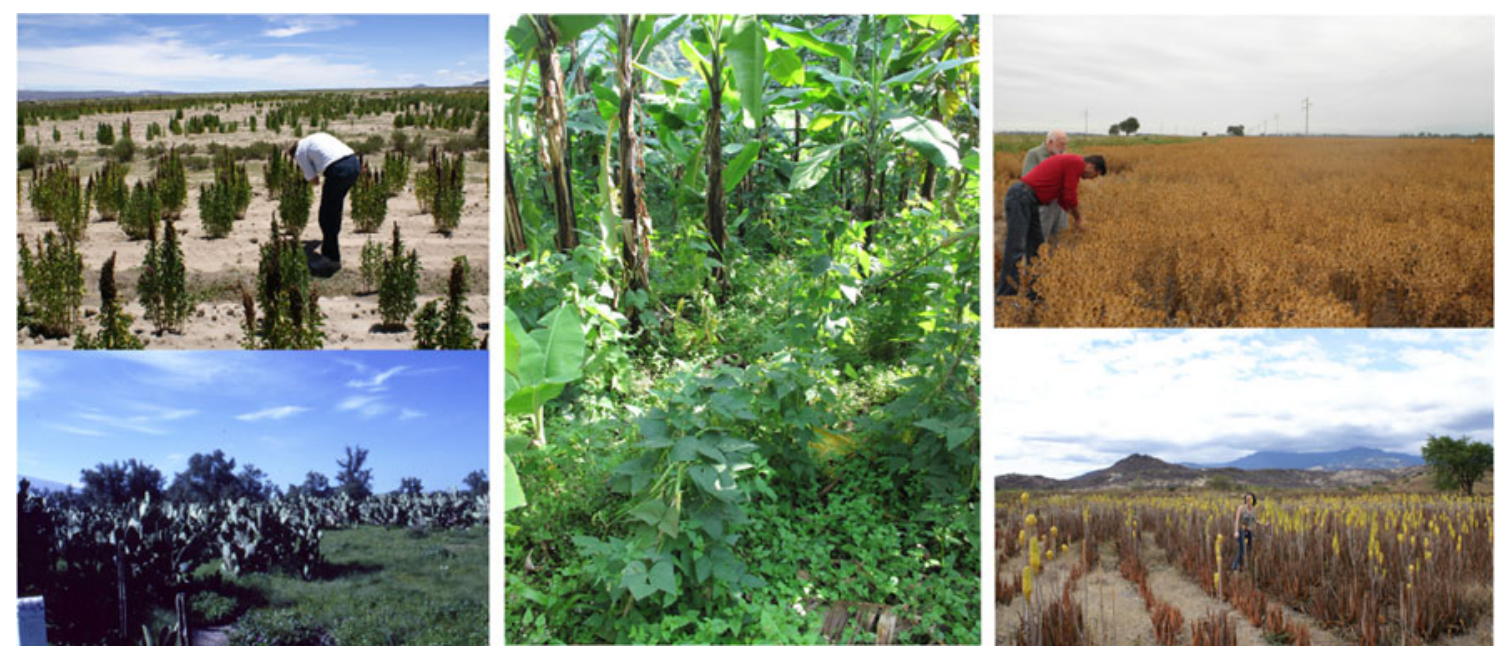

Fig. 1 Top left quinoa (Chenopodium quinoa) field north of the Salar de Uyuni, Dept. Potosi, Bolivia; below left field of nopales (Opuntia ficus-indica), State of México, Mexico; center home garden in central Uganda with plantains (Musa paradisiaca) and

common bean (Phaseolus vulgaris); top right, safflower (Carthamus tinctorius) field, NE Salta, Argentina; below right true aloe (Aloe vera), field Dept. Zacapa, Guatemala. Photos: Sven-Erik Jacobsen \& Marten Sørensen 
number of species likely to die out is growing by the day (UN 2010; Fig. 2).

While agricultural biotechnology advances rapidly in the developed world, its value for developing countries struggling to keep pace for poor human and institutional capacity challenges, causing lack of familiarity with the biotech product development process, and difficulties in navigating regulatory processes (AATF 2012) is dubious.

The private sector could partner with the public sector to contribute to the development and delivery of biotechnology tools to smallholder farmers in Africa to help overcome some of these challenges. The private sector can contribute their technologies, knowhow, and even funding. Projects where African Agricultural Technology Foundation currently participate include: Striga control in maize; development of insect-resistant cowpea; improvement of banana for resistance to banana bacterial wilt; biological control of aflatoxin; development of drought tolerance in maize; and development of nitrogen-use efficient, water-use efficient, and salt tolerant rice varieties for use by smallholder farmers in Africa.

\section{Potential for utilization of agrobiodiversity}

There is a real danger that the scientific response to the global food shortage will be based exclusively on methods that jeopardize existing diversity, even though more appropriate solutions can be found by focussing on the biological factors that determine yield: genotype, environment, and management. An analysis of the increases in Australian wheat yields over the past 100 years concluded that management contributed $50-55 \%$ of the yield increases, surpassing genotype (35-40\%), and environment (10-15\%) (Fischer 2009). It was also noted that new genotypes resulted primarily in increases in yields on the farms already high yielding, whereas management primarily improved the yield of lower-yielding farms. Future agricultural research and development must pay more attention to crop management and agronomy rather than to breeding alone if we are to address farmers and future environmental conditions globally. Productivity can increase steadily over time with low-input ecological practices on rain fed farms, if natural, social, and human capital assets are accumulated (Pretty et al. 2003). This is especially important in developing countries, where daily food acquisition is the most important task. Very low or even zero fertilizer input and yields only $25 \%$ of potential are not infrequent in developing countries, so there is huge potential for improved yields through improved agronomic practices in the near future.

We argue that food production can be best understood and increased by analyzing yield as the result of genotype, environment, management, and their interactions, and that existing biodiversity can provide the genes needed to satisfy future global demand. We should start with an analysis of available mio. EUR

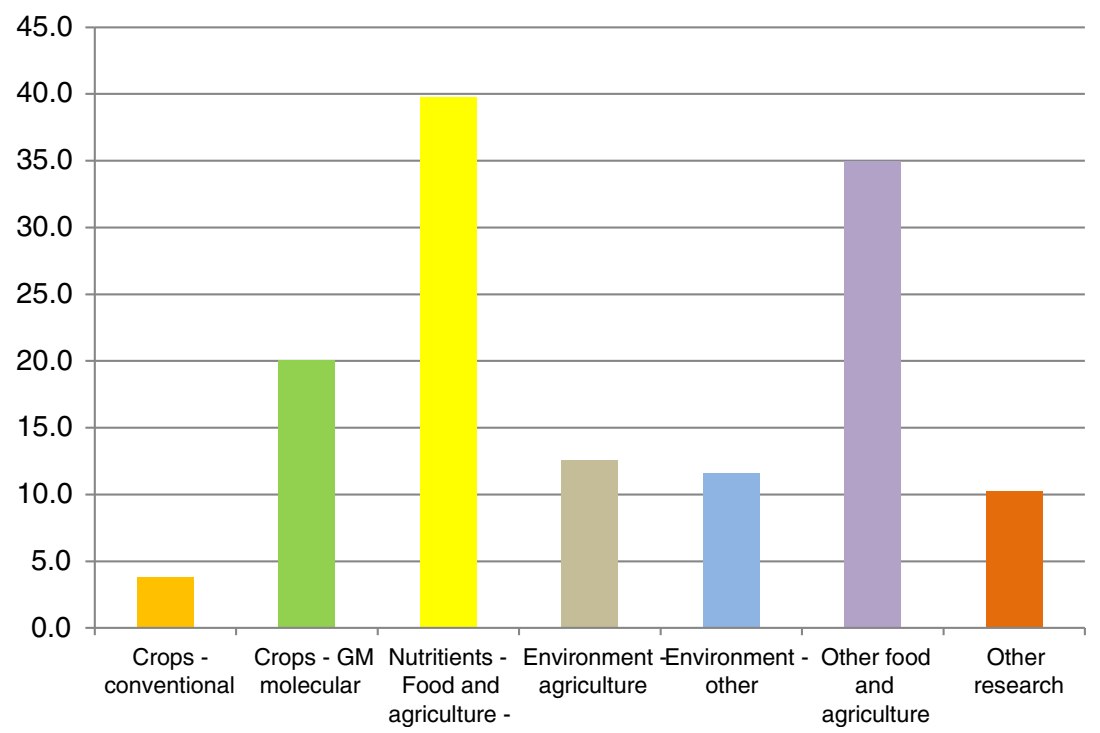

Fig. 2 Food and agricultural research funding (2006-2010) from the Danish Strategic Research Council. In millions EUR. Crops-conventional research projects that are aimed at agricultural production systems and plant breeding with field trials. Crops-GM molecular projects that mainly are based on molecular plant breeding technologies. Nutrients-food and agriculture projects that deal with nutritional processes and indirect health impact of human food consumption. Environment-agriculture projects that are related to environmental impact from agricultural production, including nutrient leaching to the surrounding environment. Environment-other projects that focus on environmental impact but mainly in other sectors than agriculture such as fisheries. Other food and agriculture research into utilization of biomass into biofuel, functional foods and animal production (including molecular and nanoscience). Other research research projects that mainly are aimed at developing pharmaceuticals and medicine 
genetic material (Porter et al. 2010). This agrobiodiversity, i.e., the cultivated plants that feed the world today, can continue to do so, if we invest in its future utilization (Padulosi et al. 2011). It is agronomically, ecologically, nutritionally, and economically risky and unsustainable to rely almost exclusively on a handful of major crops to provide food for the world's population (Dempewolf et al. 2010). We should avoid the temptation to further sacrifice Earth's already hugely depleted biodiversity for short-term, unsustainable increases in food production (Godfray et al. 2010). The EU commissioner for environment has emphasized the importance of biodiversity (Potocnik 2010), and year 2010 was designated as the "year of biodiversity" by the United Nations.

GM cultivars may also contribute to increased food production, but it remains to be seen whether their contribution is environmentally and nutritionally sustainable. Agricultural diversity can furnish the impoverished third world farmerwho often lives under difficult climatic conditions with little or no economic resources - with a better livelihood and less dependence on large international corporations. It can generate income and reliable food supply, and guarantee improved nutrition and health among the family members (Porter et al. 2010). Numerous very promising, readily available and potentially high yielding crops exist as alternatives to the major crops. The application of traditional plant breeding methods to minor crops often offers more efficient and economically attractive solutions, frequently well adapted to local agricultural conditions, and with a culturally high acceptance and utilization rate. As international aid organizations have learned, "low-tech" solutions are often much more effective and less failure-prone. However, they are also less profitable for large international corporations, which explain why GM crop development has much more economic support.

The nutritional value of many underutilized, traditionally cultivated crops is high, with ample amounts of micronutrients, antioxidants and essential amino acids for the consumer. This applies to species from the Andes, e.g., quinoa, amaranth, kañawa, and Andean lupine (Jacobsen 2003, 2011; Jacobsen et al. 2003), all of which are known for their high tolerance to drought, soil salinity, and other climatic extremes, factors likely to occur with increased frequency in the future due to climate change (IPCC 2007). Small-grained African cereals, e.g., millets, sorghum and teff (Weiner et al. 2010; Tari et al. 2012), indigenous leafy vegetables and fruits (Shackleton et al. 2009), and a range of legumes (Sørensen 2004; Jacobsen et al. 2012), represent a wealth of potentially important crops. In Asia, numerous promising local rice landraces and varieties are found. Minor crops are traditionally utilized in many ways, making them interesting from the culinary perspective. Despite their high value, the continued availability of many of these crops is endangered due to competition on unequal terms from bulk products and food aid in the form of industrially produced commercial varieties of rice, maize and wheat. The limited marketing of under-utilized crops is often caused by their need for specific processing and the local image as "poor people's food", as well as insufficient research and breeding in the local agrobiodiversity.

In Latin America, this situation is already changing for a few of the traditional crops, such as the yam bean or jícama (Pachyrhizus erosus) from Mexico, and quinoa (Chenopodium quinoa) from the Andes, which have been discovered and gained access to international markets. It could be argued that the successful cultivation and marketing of such crops has taken place in spite of the green revolution and transgenic research that has focussed on improving yields of a few major crops. Unfortunately, hundreds of other valuable species and cultivars of considerable local and potential global importance as food appear to have already been forgotten or ignored by the agricultural sector (Padulosi et al. 2011). Crop diversification is a key component for enhancing adaptation and resilience of production systems in the face of climate change. Greater demand for under-utilized species can play an important role nutritionally while in addition they serve to maintain livelihood options of the rural and urban poor (Padulosi et al. 2011).

Agriculture involving a wide range of crops ensures a diverse and varied diet vital to nutrition and health. Efforts to increase production have so far been based on extremely simplified agroecosystems using only a few varieties of even fewer crops. These crops often require massive injections of energy-dependent inputs such as fertilizers and pesticides. Such simplified systems lead to low-diversity diets that are frequently associated with high incidence of lifestyle diseases such as type 2 diabetes, heart disease, obesity and cancer (Frison 2009). Diversified agricultural systems not only render smallholder farming more sustainable, but also reduce the vulnerability of poor farmers. They minimize the risk of harvest failures caused by droughts or floods, by extremes of temperature and by outbreaks of pests and diseases, all of which will be exacerbated by climate change (Frison et al. 2011).

Agriculture's most direct negative impact on biodiversity is due to the considerable loss of natural habitats, which is caused by the conversion of natural ecosystems into agricultural land. A key question is therefore how to achieve an increased productivity on existing land. According to Carpenter (2011), GM crops have had a net positive impact on biodiversity and sustainability over the past 15 years by increasing yields, decreasing insecticide use, increasing use of more environmentally friendly herbicides, and facilitating adoption of conservation tillage. However, the use of gene technology may endanger the rich diversity of certain species, which for instance is discussed when considering the introduction of Bt eggplant in the middle of the genetic center for the crop in India (Kolady and Lesser 2012). 


\section{The value of agrobiodiversity}

There is much evidence that global agriculture would benefit from an intensified utilization of existing biodiversity. There is a growing interest in exotic foods, which have become readily available as a result of cheap and easy transport and efficient marketing. As the consumer demand for novel products has increased dramatically, supermarkets today offer food from many corners of the world, products that a couple of decades ago were available in a few parts of the world only (Rudebjer 2009). In order to retain long term, efficient, and economically attractive possibilities for utilization of agrobiodiversity, it is essential to consider the threats to the exploitation of existing biodiversity from agricultural industrialisation; plant breeding aimed at a few crop species; weeds, pests, and diseases; and climate change (Grum 2009).

We need to shift the focus of agricultural research from genes alone to management and their interactions. There is a lot to gain, as shown in a study with mixed cropping where plots with 16 species produced 2.7 times more biomass than monocultures (Tilman et al. 2001). Comparing meadows with different number of species, the richer meadows yielded $43 \%$ more hay after 8 years than species-poor fields, an effect that was not due simply to the fertilizing effects of the greater number of legumes in the more diverse fields (Bullock et al. 2007). This is generally true for grasslands across Europe (Hector and Loreau 2005), and increased grassland diversity promotes temporal stability at many levels of ecosystem organization (Proulx et al. 2010). Mixtures of barley varieties in Poland generally out-yielded the mean of the varieties as pure stands (Finckh et al. 2000). The highly intensive agricultural system of home gardens are some of the most diverse production systems in the world and also some of the most productive (Eyzaguirre
2004; Galluzzi et al. 2010). Although they are usually highly labor intensive and small, they nonetheless provide direct benefits in terms of production, income and nutrition for millions of small-scale farmers throughout the world. Agricultural biodiversity can reduce year-to-year variation, thus contributing to stability in yield as confirmed by studies in Brazil and Senegal (Nair 2001; Brun et al. 1989).

It is clear that a global effort is needed to further develop crops already adapted to specific ecological conditions, e.g., African and Asian cereals, and Andean seeds, roots and tuber crops, which have demonstrated their capability of securing food production for a wider range of farmers and consumers. The majority of these crops are hardly known outside their present area of cultivation. They are, however, characterized by their favorable nutritional qualities and their reliability in production. Already at the UN conference in Rio de Janeiro in 1995 on "environment and sustainable development", there was a general consensus that the world's food supply and nutrition is most secure if based on the broadest possible range of crops. In a world where meeting the food demand of a growing population continuously becomes a more serious challenge, it is obvious that the right choice of crops and cropping systems is critical. In areas where climatic conditions are unstable, such as in many developing countries, local agriculture relies traditionally on a range of crops. This is the best method for increasing the reliability of food production in the face of seasonal variation.

Anyone who has lived in rural areas of Africa or the Far East will have observed how little variation there is in the daily diet: porridge, e.g., manioc, plantain, maize, or rice, with few protein-rich additions. Prior to the introduction of manioc and cereals like maize and rice the diets in these regions were based on a wide range of crops. Would it not

Table 2 Estimates for minor crops of increasing importance as food products in USA, 2010

\begin{tabular}{llclc}
\hline Crop & US import (t) & Yield ( $\mathrm{t} \mathrm{ha}^{-1}$ ) & Export (\% of total) & $\begin{array}{c}\text { Total area for export } \\
\text { to US (ha) }\end{array}$ \\
\hline Yam-bean $^{\mathrm{a}}$ & 38,668 & 50.0 & 40 & 1,933 \\
Quinoa $^{\mathrm{b}}$ & 1,500 & 0.6 & 80 & 3,125 \\
Amaranth $^{\mathrm{b}}$ & 1,000 & 0.8 & 70 & 1,786 \\
Manioc $^{\mathrm{a}}$ & 43,593 & 9.6 & 40 & 11,352 \\
Sweet potato (world) $^{\mathrm{c}}$ & 128 & 5.9 & 35 & 62 \\
Sweet potato (USA) $^{\mathrm{d}}$ & 1,082 & 5.9 & 35 & 524 \\
Taro $^{\mathrm{a}}$ & 41,813 & 6.8 & 35 & 17,569 \\
\hline
\end{tabular}

${ }^{a}$ United States Department of Agriculture, Agricultural Marketing Service, Fruit \& Vegetable Market News, 2010

${ }^{\mathrm{b}} \mathrm{FAO}(2010)$

${ }^{\mathrm{c}}$ Bureau of the Census, U.S. Department of Commerce

${ }^{\mathrm{d}}$ http://usda.mannlib.cornell.edu/MannUsda/homepage.do;jsessionid=62D429418A53EC7CC9E2B596107FA580 
be much more sensible in terms of nutrition and palatability, to enjoy a diet involving a range of vegetables, starch, and protein plants as well as fruits, rather than a few crops?

\section{What are we going to feed the world?}

Below, we present an example from the USA on the adoption of new food products based on exotic, minor crops, produced mainly in the developing world using local agrobiodiversity and representing alternatives to GM crop development and marketing. Several of these tropical crops have become important in the USA, in part because of immigration from Latin America (Table 2). Several South American species, some of exceptional high nutritional value, such as the root crop yautia or cocoyam (Xanthosoma spp.), have become popular foods, but also seed crops as quinoa and amaranth are very popular in the USA. For sweet potato, there is also an internal production of almost ten times the import, which adds to the figure. In addition, USA is now producing African crops like sorghum and millet, and an Asian crop like sesame, on commercial, large-scale basis.

Many arguments about "feeding the world" assume that we need more of our current, western diet, but it should be obvious that the world's population can better be fed, both agriculturally, environmentally and with respect to human health, with a diet different from what is most common in the developed world today. It is clear that feeding the world will require eating lower on the food chain, i.e., fewer animal products and more plant products (Duchin 2005). An increase in the variety of plant foods can contribute to this goal.

\section{Conclusion}

There is a wide range of existing and emerging problems related to food security that can be tackled by a range of crop technologies (FAO 2010). Key areas include pest and disease control, salt and drought-tolerance, crop yield and quality, and the sustainability and environmental impact of crop production. The knowledge gained from basic plant research will underpin future crop improvements, but effective mechanisms for the rapid and effective translation of research discoveries into public good agriculture remain to be developed. Maximum benefit will be derived if robust plant breeding and crop management programmes have ready access to all the modern crop biotechniques, both transgenic and nontransgenic, to address food security issues. This will require additional investments in capacity building for research and development in developing countries. Technology implementation alone is not sufficient to address such complex questions as food security. Biotechnologies will make new options available, but their uptake and effective exploitation will rely on an intricate web of cross-sectorial factors (FAO 2010).

Although there are positive aspects of the use of biotechnology in the cases where it is superior to conventional breeding, good nutrition depends on adequate intakes of a range of nutrients and other compounds (Bouisa et al. 2003). We maintain that the best way to eliminate undernutrition worldwide is to provide increased consumption of a range of nonstaple foods. By reducing the cost of producing food, biotechnology will, possibly, make its most important contribution to reducing malnutrition. Albeit if this is to be achieved it will require several decades of informed government policies, a large investment in agricultural research, and other public and on-farm infrastructure (Bouisa et al. 2003).

When scientists seek to improve crops by adding drought, pest, or disease tolerance through the application of GM technology, they risk turning a blind eye to the study of cultivated plant materials, which already possess many of the desired traits. The documented improvements in yield of soybean, maize and other GM crops to date have not been impressive if they are to be found at all. The overemphasis on genetic engineering is obscuring our knowledge of the considerable available diversity of eminently adapted alternatives, which could provide a greater supply reliability and nutritional enrichment compared to a diet based on few crops only. The existing diversity with its many beneficial characteristics has appeared to be ignored or forgotten in developing as well as in developed countries.

GM efforts to date have been focused on crops considered to be profitable enough by large plant breeding companies, not on solutions to problems confronted by the world's farmers or consumers. GMOs developed by these companies will not help most of the world's farmers. On the contrary, they are expensive and increase the dependency of farmers on external inputs, and have a negative impact on income distributions. Utilizing existing biodiversity and traditional breeding methods are more appropriate and constitutes more promising approaches if our goal is to feed the world with nutritious and reliable plant products. The claim that GMOs are necessary to feed the world is no more than a self-serving advertising campaign, and it is unfortunate that some economists, accept the claims of GMO proponents as a "technical fix" to the world's food problems without skepticism. The development of GM technology is not driven by demand pull or public science push, but primarily by corporate interests, supported by GMO researchers' career interests.

Not only is GMO research an ineffective way to address these problems. GM crops can threaten the cultivation of minor crops, such as neglected and underutilized plant species, which today constitute the basis of much subsistence farming. GM crops will reduce the nutritional value and yield reliability of the food supply, and lead to a dangerous loss of biodiversity. For a range of traits, the potential of 
existing agrobiodiversity for cures for human diseases, resistance to plants pests and diseases, adaptation to climatic changes, and nutritional attractiveness is enormous. Existing biodiversity in combination with plant breeding has much more to offer the many world's farmers and consumers, while GMOs have more to offer the agro-industry and some large-scale farms, and this explains why they have received so much attention and research funding.

GMO research should be seen as basic research, very much worth pursuing as such and with potential applications over the long term, but it is cannot be seen as good strategic research directed at increasing world food production within the coming decades. Rather, emphasis on (1) improved agricultural practices in hunger-prone developing countries, (2) development of agrobiodiversity resources through plant breeding, and (3) more sustainable consumption as well as production of foodstuffs, could be the basis for a much better strategy if the goal is to feed the world's population in the coming decades.

In short, the available evidence supports a focus on agrobiodiversity as a more appropriate technology to secure food production in a sufficiently high quantity and quality in the years to come than GM technology.

\section{References}

AATF (African Agricultural Technology Foundation) (2012) Support biotechnology development in Africa-private sector urged. Press release AATF. http://www.aatf-africa.org, 3 p.

Ahmed I (2012) Killer seeds: the devastating impacts of Monsanto's genetically modified seeds in India. Global Research. http:// www.globalresearch.ca/killer-seeds-the-devastating-impacts-ofmonsanto-s-genetically-modified-seeds-in-india/. Accessed: 12 Jan 2012

Alnwick D (1996) Significance of micronutrient deficiencies in developing and industrialized countries. In: Combs GF, Welch RM, Duxbury JM, Uphoff NT, Nesheim MC (eds) Food-based approaches to preventing micronutrient malnutrition. An international research agenda. Cornell University, Ithaca, NY, USA

Barta P (2007) Feeding billions, a grain at a time. The Wall Street Journal, pp. A1. http://online.wsj.com/article/SB118556810848880619.html. 28 July 2007

Beyer P (2010) Golden rice and 'golden' crops for human nutrition. New Biotechnol 27:478-481

Borlaug NE (2000) Ending world hunger. The promise of biotechnology and the threat of antiscience zealotry. Plant Physiol 124:487-490

Bouisa HE, Chassyb BM, Ochandac JO (2003) Genetically modified food crops and their contribution to human nutrition and food quality. Trends Food Sci Technol 14:191-209

Brookes G (2002) The farm level impact of using Bt maize in Spain. PG Economics, UK

Brun T, Reynaud J, Chevassus-Agnes S (1989) Food and nutritional impact of one home garden project in Senegal. Ecol Food Nutr 23:91-108

Bullock JM, Pywell RF, Walker KJ (2007) Long-term enhancement of agricultural production by restoration of biodiversity. J Appl Ecol 44:6-12
Burke M, Lobell D, Guarino L (2009) Shifts in African crop climates by 2050 , and the implications for crop improvement and genetic resources conservation. Glob Environ Change 19:317-325

Carpenter JE (2010) Peer-reviewed surveys indicate positive impact of commercialized GM crops. Nat Biotechnol 28(4):319-321

Carpenter JE (2011) Impacts of GE crops on biodiversity. ISB News Report June 2011, 4 p.

Carpenter JE, Gianessi L (1999) Herbicide tolerant soybeans: why growers are adopting roundup ready varieties. AgBio-Forum 2(2):65-72

Conner AJ, Mercer CF (2007) Breeding for success: diversity in action. Euphytica 154:261-262

Danish Ministry of Food Agriculture and Fisheries (2009) GM cropswhat can it be used for? [in Danish: Fødevareministeriet GMO Hvad kan vi bruge det til?], Fødevareministeriet. September 2009. $236 \mathrm{p}$.

Dempewolf H, Bordoni P, Rieseberg LH, Engels JMM (2010) Food security: crop species diversity. Science 328:169-170

Duchin F (2005) Sustainable consumption of food: a framework for analyzing scenarios about changes in diets. J Ind Ecol 9:99-114

Enriquez J (2001) Green biotechnology and European competitiveness. Trends Biotechnol 19(4):135-139

European Union (2010) A decade of EU-funded GMO research (20012010). ISBN 978-92-79-16344-9. doi:10.2777/97784. 268 p

Eyzaguirre PB, Linares OF (2004) Home gardens and agrobiodiversity. Smithsonian, Washington, DC, USA

FAO (2007) The state of food and agriculture. Rome, xiv. 222 p.

FAO (2010) Agricultural biotechnologies in developing countries: options and opportunities in crops, forestry, livestock, fisheries and agro-industry to face the challenges of food insecurity and climate change (ABDC-10). FAO International Technical Conference, Guadalajara, Mexico, $65 \mathrm{p}$

Finckh MR, Gacek ES, Goyeau H, Lannou C, Merz U, Mundt CC, Munk L, Nadziak J, Newton AC, De Vallavielle-Pope C, Wolfe MS (2000) Cereal variety and species mixtures in practice, with emphasis on disease resistance. Agronomie 20:813-837

Fischer RA (2009) Farming systems of Australia: exploiting the synergy between genetic improvement and agronomy in crop physiology. In: Sadras V, Calderini D (eds). Elsevier: Amsterdam, pp 23-54

Frison E (2009) Director General calls for investment in true food security. Biodiversity news. http://www.bioversityinternational.org/ news and events/news/news/article.

Frison E, Cherfas J, Hodgkin T (2011) Agricultural biodiversity is essential for a sustainable improvement in food and nutrition security. Sustainability 3:238-253

Galluzzi G, Eyzaguirre P, Negri V (2010) Home gardens: neglected hotspots of agro-biodiversity and cultural diversity. Biodivers Conserv 19:3635-3654

Gassmann AJ, Petzold-Maxwell JL, Keweshan R, Dunbar MW (2011) Field-evolved resistance to Bt maize by western corn rootworm. PLoS One 6(7):e22629. doi:10.1371/journal.pone.0022629

Gepts P (2002) A comparison between crop domestication, classical plant breeding, and genetic engineering. Crop Sci 42(6):1780-1790

Gepts P (2006) Plant genetic resources conservation and utilization: the accomplishments and future of a societal insurance policy. Crop Sci 46:2278-2292

GM Compass (2009) Commercial GM crops in the EU in 2008. http:// www.GMcompass.org/eng/agri biotechnology/GM_planting/ \%3E392.gm_maize_cultivation_europe_2008.html.

Godfray HCJ, Beddington JR, Crute IR, Haddad L, Lawrence D, Muir JF, Pretty J, Robinson S, Thomas SM, Toulmin C (2010) Food security: the challenge of feeding 9 billion people. Science 327:812-817

Gouse M, Pray C, Schimmelpfennig D, Kirsten J (2006) Three seasons of subsistence insect-resistant maize in South Africa: have smallholders benefited? AgBioforum 9:15-22 
Gruère GP, Sun Y (2012) Measuring the contribution of Bt cotton adoption to India's cotton yields leap. IFPRI Discussion Paper 01170, $28 \mathrm{p}$.

Gruère GP, Giuliani A, Smale M (2008) Marketing underutilized plant species for the benefit of the poor: a conceptual framework. In: Kontoleon A, Pasqual U, Smale M (eds) Agrobiodiversity conservation and economic development. Routledge, Abingdon, UK, pp 73-87

Grum M (2009) Threats to biodiversity. In: Rudebjer P, Van Schlagen B, Chakeredza S, Karnau H (eds). Proc. Learning agrobiodiversity: options for universities in Sub-Saharan Africa. 21-23 January 2009, Nairobi, Kenya, pp 78-80

Guillaume P, Gruère, Purvi Mehta-Bhatt P, Sengupta D (2008) Bt cotton and farmer suicides in India, reviewing the evidence. IFPRI Discussion Paper 00808. International Food Policy Institute (IFPRI). http://www.ifpri.org/publication/bt-cotton-andfarmer-suicides-india

Gurian-Sherman D (2009) Failure to yield - evaluating the performance of genetically engineered crops. Union of Concerned Scientists, $51 \mathrm{p}$.

Hall L, Dexter J, Jhala A, McPherson M (2009) Biology matters: seedand pollen-mediated gene flow in three oilseed crops, safflower, flax and oilseed rape. GMCC-09 Adelaide. http://www.gmcc09.com/wp-content/uploads/hall.pdf.

Hector A, Loreau M (2005) Relationships between biodiversity and production in grasslands at local and regional scales. In: McGilloway DA (ed) Grassland: a global resource. Wageningen Academic, Wageningen, The Netherlands, pp 295-304

Huang J, Pray C, Rozelle S (2002) Enhancing the crops to feed the poor. Nature 418:678-684

IAASTD (2009) Agriculture at a crossroads. International Assessment of Agricultural Knowledge, Science and Technology for Development (IAASTD), $250 \mathrm{p}$.

IFOAM (2009) Organic agriculture - a guide to climate change and food security. http://www.ifoam.org/growing_organic/1_arguments_for oa/environmental_benefits/pdfs/IFOAM-CC-Guide-Web.pdf

IPCC (2007) Climate change 2007: synthesis report, contribution of working groups I, II and III to the fourth assessment report of the intergovernmental panel on climate change. Pachauri RK, Reisinger A (eds). IPCC: Geneva, Switzerland, $104 \mathrm{p}$

ISF (International Seed Federation) (2011) Agriculture under pressure. http://www.worldseed.org/isf/home.html

ISIS (2010) Farmer suicides and Bt cotton nightmare unfolding in India. ISIS Report 06/01/10. www.i-sis.org.uk, $17 \mathrm{p}$.

Jacobsen S-E (2003) The worldwide potential for quinoa (Chenopodium quinoa Willd.). Food Rev Int 19:167-177

Jacobsen S-E (2011) The situation for Quinoa and its production in Southern Bolivia: from economic success to environmental disaster. J Agron Crop Sci 197:390-399

Jacobsen S-E, Mujica A, Ortiz R (2003) The global potential for quinoa and other Andean crops. Food Rev Int 19:139-148

Jacobsen S-E, Jensen CR, Liu F (2012) Improving crop production in the arid Mediterranean climate. Field Crops Res 128:34-47

Jain HK (2010) Green revolution: history, impact and future. Studium Press, Housten

James C (2011) Global status of commercialized biotech/GM crops: 2011. ISAAA Brief No. 43. ISAAA, Ithaca, NY

Juma C (2011) The new harvest - agricultural innovations in Africa. Oxford University Press, Oxford, p 296

Kolady DE, Lesser W (2012) Genetically-engineered crops and their effects on varietal diversity: a case of Bt eggplant in India. Agric Human Values 29:3-15

Lal R (2008) Soils and sustainable agriculture. A review. Agron Sustain Dev 28:57-64

Larigauderie A, Mooney HA (2010) The international year of biodiversity: an opportunity to strengthen the science-policy interface for biodiversity and ecosystem services. Editorial overview. Curr Opin Environ Sustain 2:1-2
Lawson LG, Larsen AS, Pedersen SM, Gylling M (2009) Perceptions of genetically modified crops among Danish farmers. Acta Agr Scand, C-F E 6(2):99-118

Lichtfouse E, Navarrete M, Debaeke P, Souchere V, Alberola C, Menassieu J (2009) Agronomy for sustainable agriculture. A review. Agron Sustain Dev 29:1-6

Nair PKR (2001) Do tropical homegardens elude science, or is it the other way around? Agroforest Syst 53:239-245

NAS [National Academy of Sciences] (2010) The impact of genetically engineered crops on farm sustainability in the United States. National Academies: NW Washington, D.C. www.nap.edu.

Padulosi S, Heywood V, Hunter D, Jarvis A (2011) Underutilized species and climate change: current status and outlook. In: Yadav SS, Redden RJ, Hatfield JL, Lotze-Campen H, Hall AE (eds) Crop adaptation to climate change, 1st edn. Wiley, New York, pp 507-521

Parry MAJ, Hawkesford MJ (2012) An integrated approach to crop genetic improvement. J Integr Plant Biol 54:250-259

Pingali P, Raney T (2005) From the green revolution to the gene revolution: how will the poor fare? ESA working paper no. 0509. www.fao.org/es/esa, $17 \mathrm{p}$.

Pinstrup-Andersen P (2010a) Ny viden er farlig for en ideologi, som har spillet fallit. Jord og Viden 4:8-10

Pinstrup-Andersen P (2010b) The advantages of genetic engineering in agriculture include increased food production and reduced hunger -benefits for hungry and malnourished in developing countries outweigh disadvantages. http://www.monsanto.com/biotech-GM/ asp/experts.asp?id=PinstrupAndersen\#mid.

Porter JR, Challinor A, Ewert F, Falloon P, Fischer T, Gregory P, Van Ittersum MK, Olesen JE, Moore KJ, Rosenzweig C, Smith P (2010) Food security: focus on agriculture. Science 328:172

Potocnik J (2010) Green living. Parliament Magazine 31 May 2010, pp $40-41$.

Pretty JN, Morison JIL, Hine RE (2003) Reducing food poverty by increasing agricultural sustainability in developing countries. Agr Ecosyst Environ 95:217-234

Proulx R, Wirth C, Voigt W, Weigelt A, Roscher C, Attinger S, Baade J, Barnard RL, Buchmann N, Buscot F, Eisenhauer N, Fischer M, Gleixner G, Halle S, Hildebrandt A, Kowalski E, Kuu A, Lange M, Milcu A, Niklaus PA, Oelmann Y, Rosenkranz S, Sabais A, Scherber C, Scherer-Lorenzen M, Scheu S, Schulze E-D, Schumacher J, Schwichtenberg G, Soussana J-F, Temperton VM, Weisser WW, Wilcke W, Schmid B (2010) Diversity promotes temporal stability across levels of ecosystem organization in experimental grasslands. PLoS One 5:e13382

Qaim M (2009) The economics of genetically modified crops. Annu Rev Res Econ 1:665-693

Rudebjer P (2009) Agrobiodiversity in food systems, ecosystems and education systems. In: Rudebjer P, Van Schlagen B, Chakeredza S, Karnau $\mathrm{H}$ (eds). Proc. Learning agrobiodiversity: options for universities in Sub-Saharan Africa. 21-23 January 2009. Nairobi, Kenya, pp 28-33

Salinger G (2012) Five agricultural innovations to improve biodiversity. http://blogs.worldwatch.org/nourishingtheplanet/fiveagricultural-innovations-to-improve-biodiversity/

Shackleton CM, Pasquini MW, Drescher AW (2009) African indigenous vegetables in urban agriculture. Earthscan, London

Schiøler E, Pinstrup-Andersen P (2009) Seeds of contention. Oxford University Press, Oxford, p 164

Scientific American (2009) Do seed companies control GM crop research? Sci Am 13 August 2009. http://www.scientificamerican.com/ article.cfm?id=do-seed-companies-control-gm-crop-research

Stone GD (2010) The anthropology of genetically modified crops. Annu Rev Anthropol 39:381-400. doi:10.1146/annurev.anthro.012809.105058

Sørensen M (2004) Supercrop-the yam bean. Nat Hist Mag 113(3):38-43

Tari I, Laskay G, Takacs Z, Poor P (2012) Response of Sorghum to abiotic stresses: a review. J Agro Crop Sci. doi:10.1111/jac.12017 
Tilman D, Reich PB, Knops J, Wedin D, Mielke T, Lehman C (2001) Diversity and productivity in a long-term grassland experiment. Science 294:843-845

Tirado R, Johnston P (2010) Food security: GM crops threaten biodiversity. Science 328:170-171

Trewavas A (2002) GM food is the best option we have. In: Pence G (ed) The ethics of food, a reader for the twenty-first century. Rowman, Lanham, pp 148-155

Ulukan H (2009) The evolution of cultivated plant species: classical plant breeding versus genetic engineering. Plant Syst Evol 280:133-142

UN (2010) 2015 Millenium development goals. United Nations Summit 20-22 September 2010, New York, High-level Plenary Meeting of the General Assembly. UN Department of Public Information-DPI/2650 G,. September 2010

USDA (2007/2010) National Agricultural Statistics Service (NASS). Agricultural Statistics Board, US Department of Agriculture Acreage.
Vandana SV, Barker D, Lockhart C (2011) The GMO emperor has no clothes - a global citizens report on the state of GMOs, synthesis report. Navdanya International. http://image.guardian.co.uk/sys-files/ Environment/documents/2011/10/19/GMOEMPEROR.pdf

Vidal J (2011a) GM foods: a "biotech revolution"? Guardian.co.uk, 19 October 2011

Vidal J (2011b) GM crops promote superweeds, food insecurity and pesticides, say NGOs. Guardian.co.uk, 19 October 2011

Wang S, Just DR, Pinstrup-Andersen P (2008) Bt-cotton and secondary pests. Int J Biotechnol 10:113-120

Wang ZJ, Lin H, Huang J, Hu R, Rozelle S, Pray C (2009) Bt cotton in China: are secondary insect infestations offsetting the benefits in farmer fields? Agr Sci China 8(1):83-90

Weiner J, Andersen SB, Wille WKM, Griepentrog HW, Olsen JM (2010) Evolutionary agroecology: the potential for cooperative, high density, weed-suppressing cereals. Evol Applic 3:473-475

Welch RM, Graham RD (2004) Breeding for micronutrients in staple food crops from a human nutrition perspective. J Exp Bot 55:353-364 